\title{
Test Excavations of Site 41NL20 Nolan County, Texas
}

Jerry Henderson

Follow this and additional works at: https://scholarworks.sfasu.edu/ita

Part of the American Material Culture Commons, Archaeological Anthropology Commons, Environmental Studies Commons, Other American Studies Commons, Other Arts and Humanities Commons, Other History of Art, Architecture, and Archaeology Commons, and the United States History Commons

Tell us how this article helped you.

This Article is brought to you for free and open access by the Center for Regional Heritage Research at SFA ScholarWorks. It has been accepted for inclusion in Index of Texas Archaeology: Open Access Gray Literature from the Lone Star State by an authorized editor of SFA ScholarWorks. For more information, please contact cdsscholarworks@sfasu.edu. 


\section{Test Excavations of Site 41NL20 Nolan County, Texas}

\section{Licensing Statement}

This is a work produced for the Texas Department of Transportation (TxDOT) by the report producer. TxDOT and the report producer jointly own all rights, title, and interest in and to all intellectual property developed under TXDOT's contract with the report producer. The report may be cited and brief passages from this publication may be reproduced without permission provided that credit is given to both TxDOT and the report producer. Permission to reprint an entire chapter, section, figures or tables must be obtained in advance from either the Supervisor of the Archeological Studies Branch, Environmental Affairs Division, Texas Department of Transportation, 125 East 11th Street, Austin, Texas, 78701 or from the report producer. 
TEST EXCAVATIONS OF SITE 41NL20

NOLAN COUNTY, TEXAS

By

Jerry Henderson

Texas

State Department of Highways and Public Transportation Highway Design Division

May 1986 


\section{ABSTRACT}

Site $41 \mathrm{NL} 20$ is located on the south terrace of Sweetwater Creek at County Road 216 in Nolan County, Texas. Archaeological testing, confined to the county road right-of-way and a temporary 50-ft. easement on the east side of the county road, was conducted by the State Department of Highways and Public Transportation (SDHPT) i n 1983 and 1986 and produced a small quantity of chert debitage and a partially intact hearth. No prehistoric tools were recovered and no concentrations of debitage or activity areas were discerned. The main portion of the site appears to lie on private property east of the tested area. That portion of the site within SDHPT jurisdiction is not thought to meet eligibility requirements for either nomination to the National Register of Historic Places or designation as a State Archeological Landmark. 
TABLE OF CONTENTS

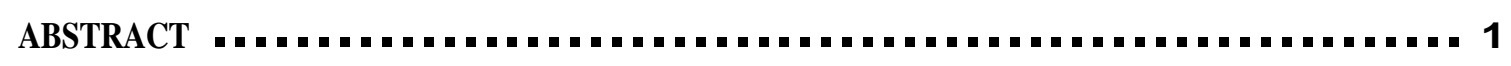

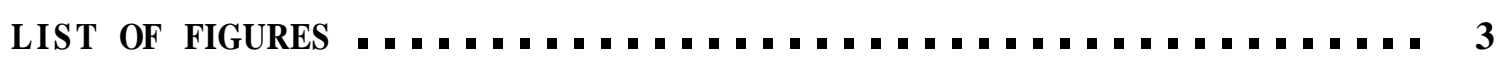

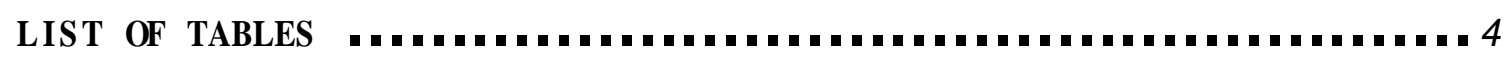

INTRODUCTION

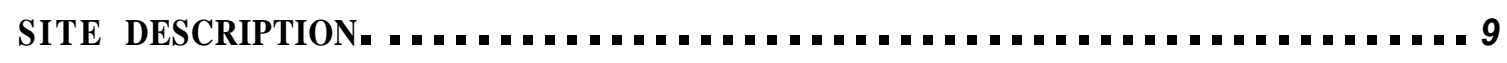

TESTING PROCEDURES AND RESULTS $\ldots \ldots \ldots$

ARCHAEOLOGICAL BACKGROUND OF THE STUDY AREA $\ldots \ldots \ldots \ldots$

CONCLUSIONS

REFERENCES CITED 


\section{LIST OF FIGURES}

FIGURE 1. Location of Site 41NL20 in Nolan County, Texas ........ 6

FIGURE 2. Contour map of Site 41NL20 showing excavation units .... 7

FIGURE 3. Profile drawing of north wall of Test Unit $3 \ldots 10$

FIGURE 4. Scraper recovered from surface of county road

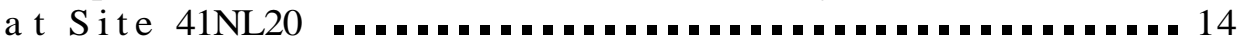

FIGURE 5. Plan view of burned rock feature at Site 41NL20 ....... 17 


\section{LIST OF TABLES}

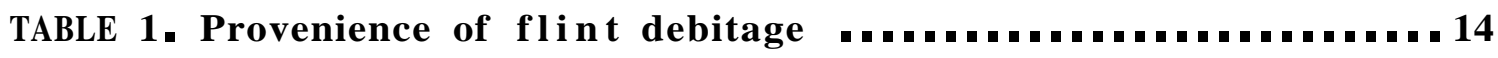

TABLE 2. Provenience of materials other than flint debitage ....... 15 


\section{INTRODUCTION}

Site 41NL20 was recorded in August 1983 by a member of the State Department of Highways and Public Transportation (SDHPT) cultural resources staff. The site was discovered during an archaeological survey performed i n response to a county bridge replacement project on County Road 216 in Nolan County, Texas. The site is on the south bank and terrace of Sweetwater Creek, at County Road 216, approximately 1.6 miles south of IH 20 near Sweetwater, Texas (Fig. 1).

The bridge replacement project which occasioned the archaeological testing of Site $41 \mathrm{NL} 20$ entails replacing the existing bridge on County Road 216 at Sweetwater Creek with a new bridge to be constructed at the same location. No new right-of-way will be required, but a temporary detour easement will be acquired on the east side of the bridge. The easement will be $330 \mathrm{ft}$. long and will extend $50 \mathrm{ft}$. east of the east right-of-way (Fig. 2). Actual traffic flow will be confined to the central portion of the easement nearest the creek (Fig. 2). The detour will be removed when the new bridge is completed. It is this easement that encroaches upon Site 41NL20 where it occurs on the south side of the creek adjacent to the county road.

It is obvious that the county road itself has breached the site in the past. Cultural materials can be seen eroding out of the cut banks, especially on the east side of the road, at an elevation higher than the present road bed, suggesting that the original road construction cut completely through the cultural deposits and removed any portions of the site which may have existed in the roadway. 


\section{This Page Redacted Per THC Policy}




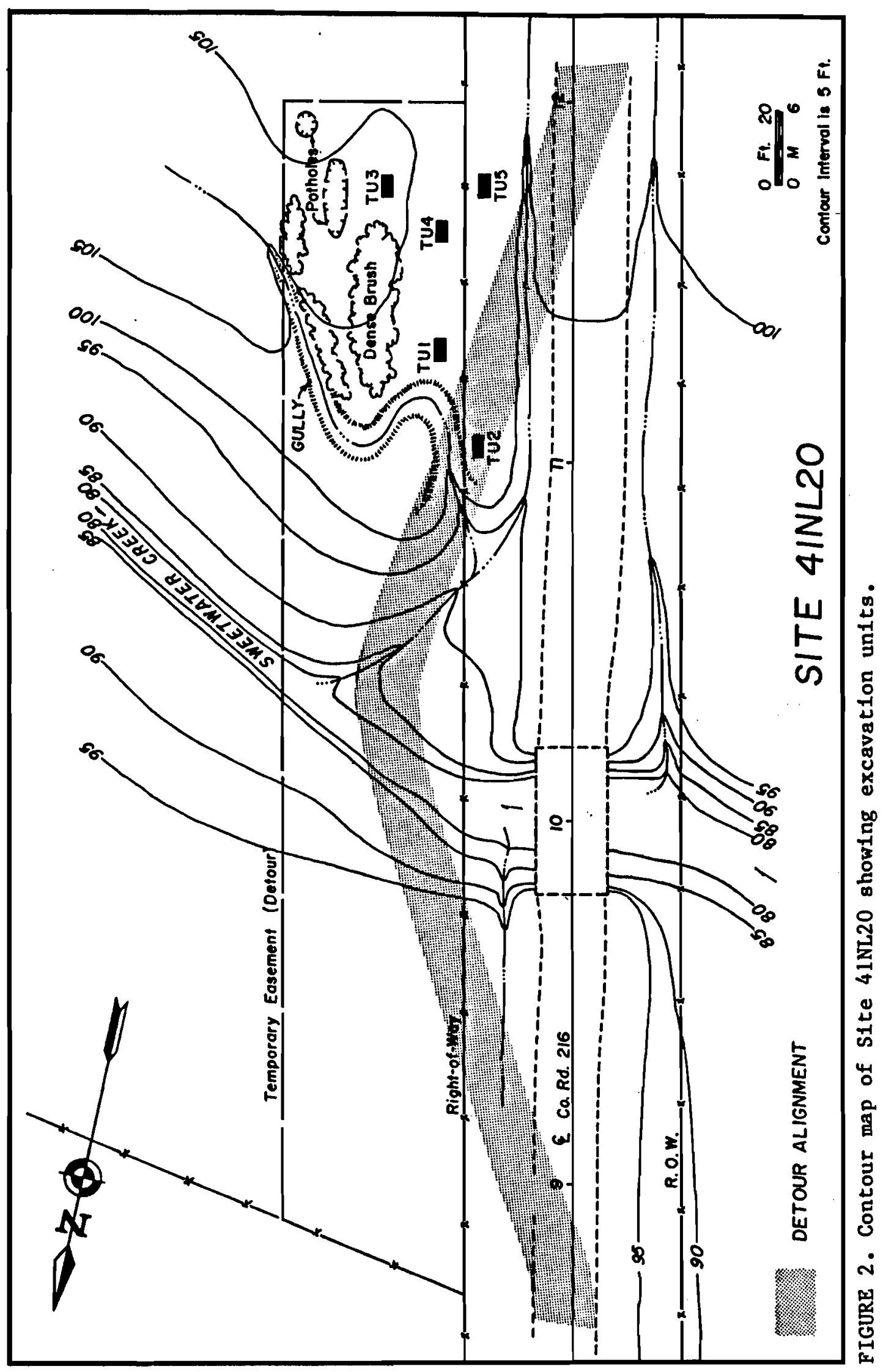


That portion of the site within the temporary easement and the portion remaining within the right-of-way were tested by a member of the SDHPT cultural resources staff in accordance with Procedures for the Protection of Historic and Cultural Properties (36 CFR, Part 800), procedures prescribed and endorsed by the Federal Highway Administration. Specific goals of the testing were to determine if the site met eligibility requirements for nomination to the National Register of Historic Places and to determine State Archeological Landmark status. After testing it was concluded that those portions of the site within SDHPT jurisdiction met neither the National Register nor State Landmark criteria.

Testing was conducted in phases. The site was tested for one day in October 1983 at which time construction plans were temporarily halted, thus interrupting the testing schedule. Testing was resumed in November 1983 and continued for three days when the bridge project was cancelled by the County and archaeological testing again was halted. In April 1986 the County renewed the bridge project and archaeological testing once again was resumed and this time completed (an additional three days of testing). Two field assistants were provided by the SDHPT Sweetwater maintenance office during the testing procedure, and a total of 152 personhours were expended. Materials recovered are being housed temporarily at the SDHPT Archaeology Laboratory in Austin until a permanent repository can be arranged. 


\section{SITE DESCRIPTION}

Sweetwater Creek and its tributaries form the major drainage system in northeastern Nolan County. In the vicinity of Site 41NL20 the creek flows in an easterly direction and dissects an area of gently sloping to rolling red-bed plains of the Woodward-Quinlan-Burson soil series (Lowther 1981). Briefly, these soils are very shallow to moderately deep permeable loams located along draws, creeks, and gullies formed i n silty and loamy red beds deposited during the Permian Period (Lowther 1981).

At Site 41NL20 the south terrace of Sweetwater Creek is relatively flat except for numerous steep-sided gullies intruding into the terrace deposits from the creek. Soils are red-to-brown silty loams becoming clayey loams as greater depths are reached (Fig. 3). A thin mantle of recent overburden averaging $11 \mathrm{~cm}$ in thickness covers the site and is presumed to have been deposited atop the intact deposits as a result of the county road-building activities.

Numerous potholes and depressions are present across the site and appear to be the result of land-clearing activities. The site is currently fallow pastureland with a dense new growth of mesquite, small brush, and cacti. Knee-high grasses and forbs are present. Large trees, primarily oak, line the creek.

The archaeological site extends eastward from County Road 216 along the south terrace of Sweetwater Creek for at least 200 meters. A westward 


\section{NORTH WALL PROFILE TEST UNIT 3}

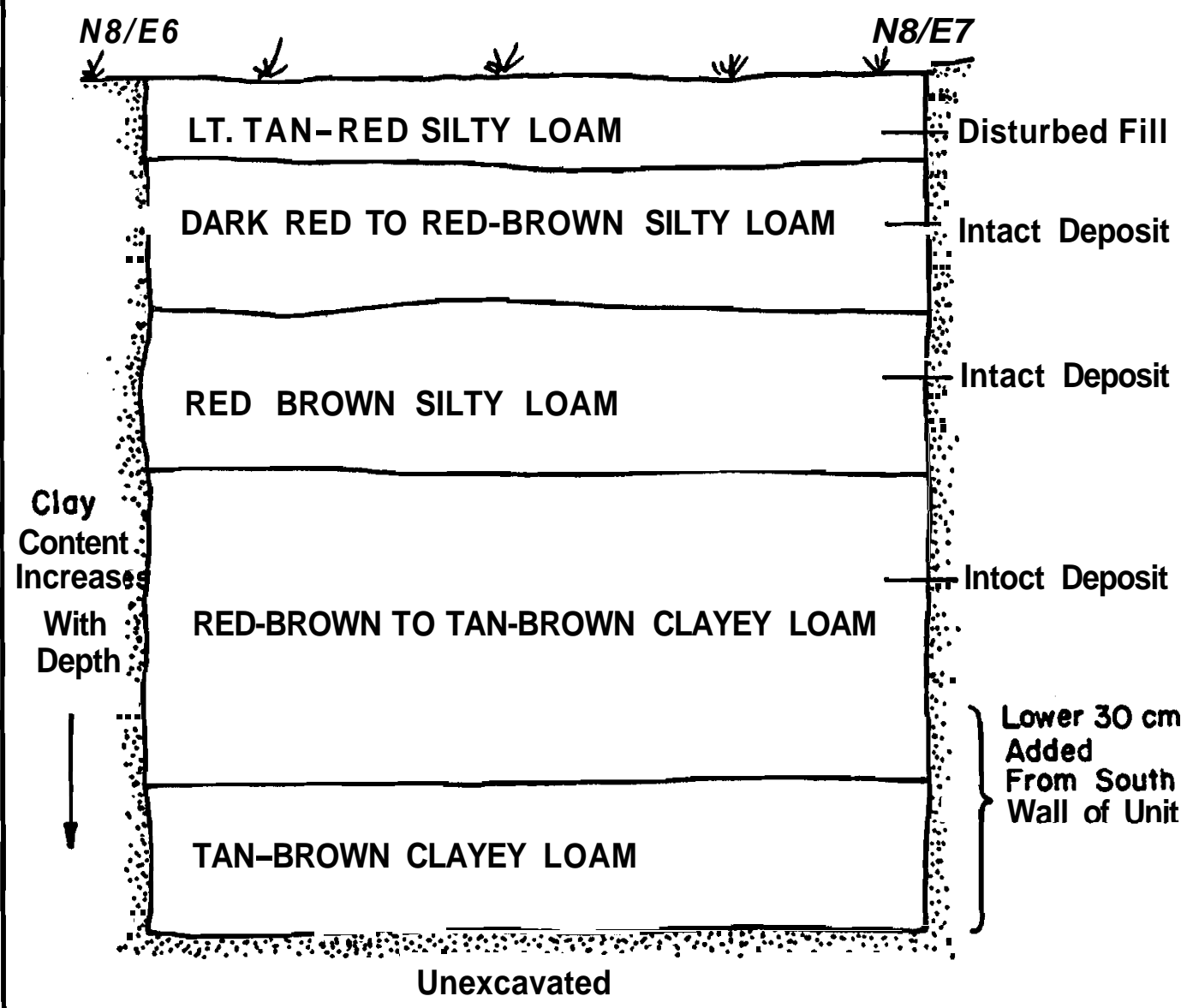

$0 \mathrm{~cm} 20$

FIGURE 3. Profile drawing of north wall of Test Unit 3. 
extension is suspected, but inability to gain access to private lands on the west side of the county road prevented determining a more precise site boundary. Evidence of aboriginal occupation along the terrace consists of chert flakes and occasional burned rocks. The flakes are most often observed on ant hills and the burned rocks can be seen washing down the side of the terrace toward the creek. Recent gullies currently dissect the terrace toward the creek, exposing buried deposits and displacing cultural material down the slopes of the gullies.

About 50 meters east of the east right-of-way fence, the density of chert and burned rocks decreases. In this area, a gully encroaches southward into the terrace from the creek and the quantity of debris seen closer to the county road is not present. A few meters farther east, the density of chert and burned rocks again increases. This surface pattern suggests that multiple occupations occurred along the terrace in a horizontal array and that the occupation tested by the SDHPT might be confined to an area extending eastward from the county road for about 50 meters. The site apparently extends southward away from the creek for about the same distance. Chert and burned rocks can be observed on the surface and also are exposed in the county road cut for about 50 meters south of the creek. 


\section{TESTING PROCEDURES AND RESULTS}

A grid system tied to permanent roadway stations was established across the site. Station Marker $12+00$ at the east right-of-way fence was designated NO/EO; and five test units, each measuring 1 by 2 meters, were aligned with the roadway centerline and were excavated. Test Unit 1 was located at N20/E2.5; Test Unit 2 was located at N28/W 0.5; Test Unit 3 was located at N6/E 7; Test Unit 4 was located at N10/E2.5; and Test Unit 5 was located at N6/W 2 (Fig.2).

Test Units 1 through 4 were positioned so as to avoid the densest stands of brush and disturbed areas, and Test Unit 5 was positioned to investigate an accumulation of burned rocks eroding from the county road cut. Units 1 through 4 were excavated in $10 \mathrm{~cm}$ vertical increments until sterile or nearly sterile deposits were reached. Unit 5 was excavated as a single level until the bottom of the burned rock feature was reached and the feature was fully exposed. After the feature was documented and removed, an additional $10-\mathrm{cm}$ level was excavated beneath the locus of the feature.

The top of a utility box marking an underground cable near Station Marker 12 on the west right-of-way line was used as a permanent vertical datum during testing and was designated an arbitrary 100 meters. Elevations were taken from this datum using a transit and stadia rod. This datum was used only for testing and did not pertain to other aspects of the bridge replacement project. 
Elevations determined that the burned rock feature in Test Unit 5 was equivalent vertically to Levels 5 and 6 in Test Units 1 through 4. Apparently 50 to $60 \mathrm{~cm}$ of soil had been removed during construction of the county road; therefore, the initial investigations in Test Unit 5 were considered to begin at Level 6.

A single scraper (Fig. 4) was recovered from the surface of the county road south of Station 12 and was added to the inventory from the site although its original provenience is unknown. It is the only prehistoric tool from the site.

A $n$ additional 617 chert flakes, 2 fence staples, 14 metal fragments, 40 glass fragments, 2 bone fragments, and 2 freshwater mussel shell fragments were recovered from the site. Tables 1 and 2 present the provenience of all recovered materials. Aside from the historic materials, chert debitage constitutes-the sum total of excavated cultural material.

From Table 1 it can be inferred that the area of densest aboriginal occupation was away from the terrace edge and toward the east. Test Unit 3 produced the greatest quantity of debitage and Test Unit 4 was the next most productive. Units 1 and 2 were virtually nonproductive. Vertically, there appears to be a slight concentration of materials in Level 2, a decrease in Level 3, and then an increase through Level 8 when once again a decrease occurs. This trend is seen only in Test Units 3 and 4 and there not definitively. Test Unit 5 appears to have been productive at the level of the burned rock feature (Level 6), but it must be noted that the total includes a surface collection from 


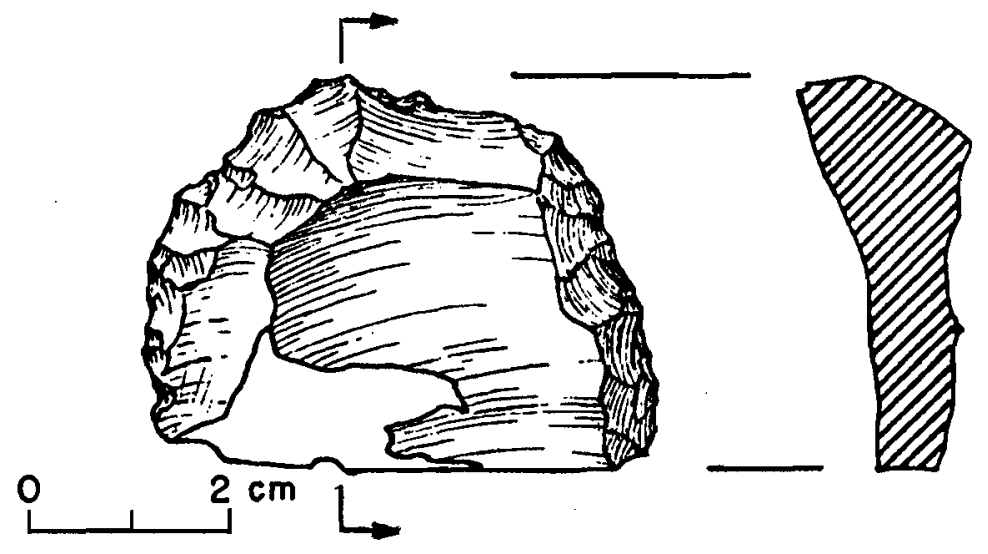

FIGURE 4. Scraper recovered from surface of county road at Site 41NL20.

TABLE 1. Provenience of flint debitage.

\begin{tabular}{|c|c|c|c|c|c|c|}
\hline Level & $\mathrm{TU} 1$ & TU 2 & $\mathrm{TU} 3$ & $\mathrm{TU} 4$ & TU 5 & Total \\
\hline 1 & 2 & 3 & 1 & 23 & & 29 \\
\hline 2 & 13 & 2 & 45 & 19 & & 79 \\
\hline 3 & 7 & 8 & 17 & 18 & & 50 \\
\hline 4 & 5 & 4 & 69 & 3 & & 81 \\
\hline 5 & 1 & 0 & 55 & 13 & & 69 \\
\hline 6 & 0 & 4 & 20 & 16 & $62 *$ & 102 \\
\hline 7 & & 0 & 44 & 17 & 14 & 75 \\
\hline 8 & & & 65 & 8 & & 73 \\
\hline 9 & & & 39 & 7 & & 46 \\
\hline 10 & & & 8 & 4 & & 12 \\
\hline 11 & & & 1 & & & 1 \\
\hline TOTALS & 28 & 21 & 364 & 128 & 76 & 617 \\
\hline
\end{tabular}

*Includes surface collection around burned rock feature. 
TABLE 2. Provenience of materials other than flint debitage.

\begin{tabular}{|c|c|c|c|c|c|c|c|}
\hline Level & Surface & TU 1 & TU 2 & TU 3 & TU 4 & TU 5 & TOTAL \\
\hline 0 & 1 scraper & & & & & & 1 \\
\hline 1 & & 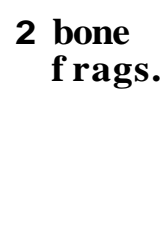 & $\begin{array}{c}2 \text { fence } \\
\text { staples } \\
2 \text { metal } \\
\text { frags. } \\
32 \text { glass } \\
\text { frags. }\end{array}$ & $\begin{array}{l}1 \text { glass } \\
\text { frag. }\end{array}$ & & & 39 \\
\hline 2 & & & & 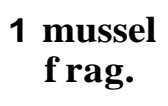 & & & 1 \\
\hline 3 & & & & & & & 0 \\
\hline 4 & & & & & & & 0 \\
\hline 5 & & & & & & & 0 \\
\hline 6 & & & & & & $\begin{array}{c}12 \text { metal } \\
\text { f rags. } \\
7 \text { glass } \\
\text { f rags. } \\
1 \text { mussel } \\
\quad \text { frag. }\end{array}$ & 20 \\
\hline 7 & & & & & & & 0 \\
\hline 8 & & & & & & & 0 \\
\hline 9 & & & & & & & 0 \\
\hline 10 & & & & & & & 0 \\
\hline 11 & & & & & & & 0 \\
\hline TOTAIS & 1 & 2 & 36 & 2 & 0 & 20 & 61 \\
\hline
\end{tabular}


around the burned rock feature. The surface materials were not in situ and probably were the results of deflation and erosion. Provenience evidence indicates that habitational surfaces or patterned occupational episodes can not be defined within the area tested.

The burned rock feature appeared to be the remains of a disturbed hearth. When first encountered, it was eroding from the east side of the county road cut and displaced burned rocks and chert had spilled down the side of the cut. After completely exposing the feature, it measured approximately 1.5 meters north-south by 1.05 meters east-west (Fig. 5). A portion in the southern part of the feature measuring approximately 70 cm in diameter appeared to be intact. In this area the rocks formed a semicircle and slanted inward toward the center. A reddish brown burned stain was present beneath a portion of this circular area, indicating in situ burning. No charcoal was encountered among or beneath the rocks or associated with the burned soil. Two chert flakes were present among the burned rocks and were considered to be part of the feature.

The feature no doubt represented a hearth and thus an integral part of a campsite locality. However, additional aspects of the campsite, other than the ubiquitous chert flakes, could not be defined within the tested area. 


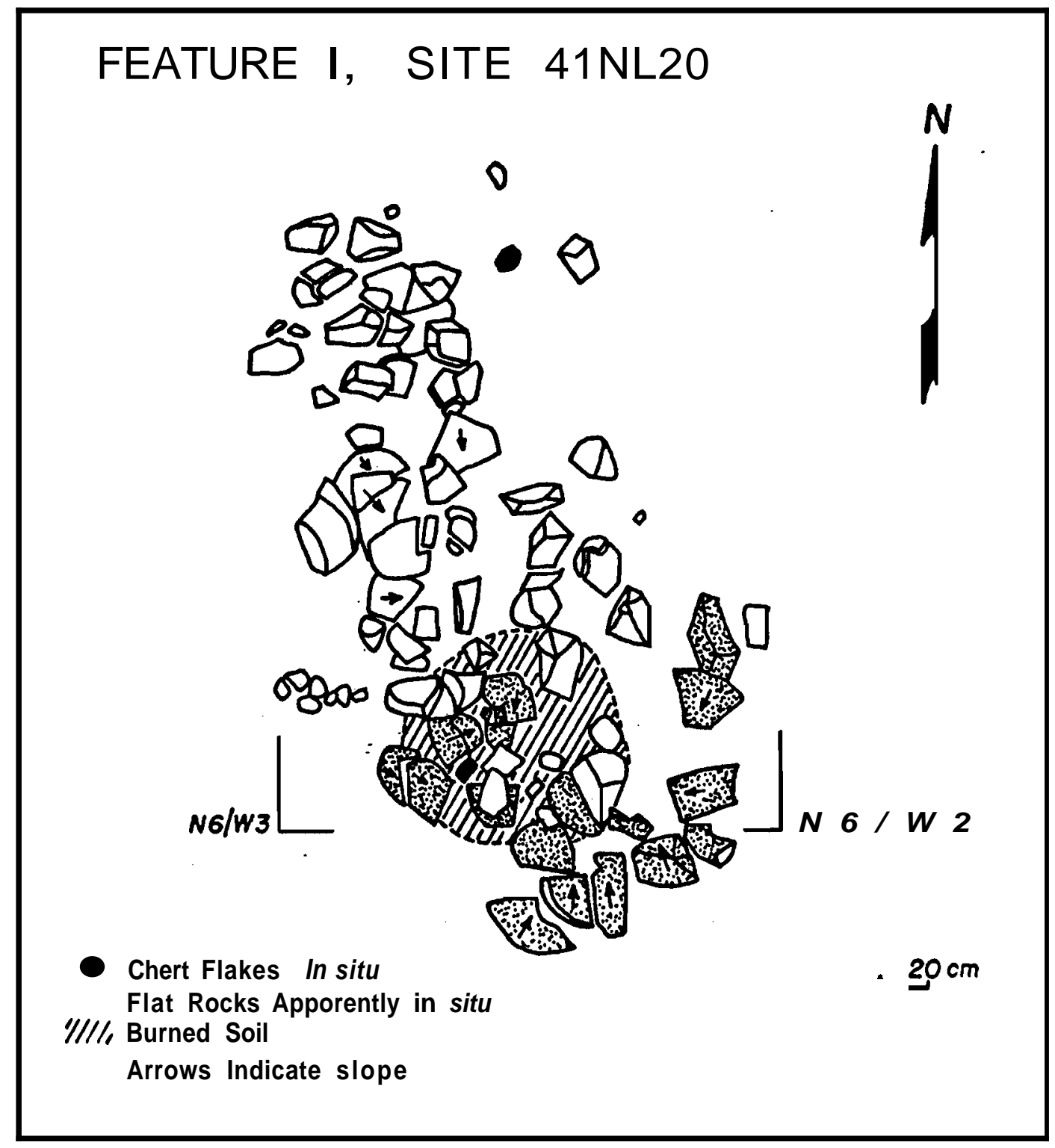

FIGURE 5. Plan view of burned rock feature at Site $41 \mathrm{NL} 20$. 
The archaeological complexes of the Nolan County area comprise four basic study units as defined by Brown et al. (1982). The earliest study unit, the Paleo-Indian, is not unlike the Paleo-Indian Period as defined throughout the state. That is, within a general time frame of 12,000 to 7500 B.P., small nomadic groups of large-game hunters moved about within a defined territory and probably occupied specific campsites on a seasonal basis. These campsites have been documented along stream and river terraces; adjacent to springs, ponds, lakes, and arroyos; in caves and underneath overhangs; and in sand dune fields (Brown et al. 1982). The primary diagnostic artifact of the Paleo-Indian Study Unit is the fluted and nonfluted lanceolate projectile point. No Paleo-Indian sites have been investigated in Nolan County although adjacent counties have produced at least three: Fisher County to the north (the Adair-Steadman Site); Taylor County to the east (the McLean Site); and Mitchell County to the west (the Lone Wolf Creek Site) (Brown e.t a 1982).

The specialized large-game hunting subsistence pattern of the PaleoIndian Period terminated largely as a result of the extinction of the chief prey species--the Pleistocene megafauna--and a new mode of subsistence was necessary. M any regional and localized adaptations arose in response to diversified environments throughout the state. In Nolan County, the period is defined as the Lower Plains Archaic Study Unit (Brown et al. 1982). The Study Unit. encompasses the time period between 8000 B.P. and A.D. 500-900, but the sequence is ill 
defined (Brown et al. 1982). Small open campsites have been associated with various landforms, and lithic workshops have been identified. A variety of dart points including corner-notched types, ovate to triangular knives, thick end scrapers, small manos, and thin grinding slabs are diagnostic of the Study Unit.

The initiation of the succeeding period, the Lower Plains Late Prehistoric Study Unit, is marked by the introduction of the bow and arrow and the appearance of ceramics (Brown et. al. 1982). The Study U nit encompasses a time frame of A.D. 500-900 to around A.D. 1528 (Brown et al. 1982). Agricultural practices were known throughout most of the state during this time but in many cases never surpassed hunting and gathering as the chief mode of subsistence. In Nolan County, the presence of arrowpoints is the chief indicator of the Lower Plains Late Prehistoric Study Unit.

The initiation of the final period, the Historic Indian Study Unit, is marked by the first identifiable evidence of contact with nonnative peoples. This Study Unit has been divided into an earlier Prehorse Plains Culture and a later Late Shoshonean-Language Group (Brown et al. 1982). Very little archaeological evidence has been uncovered from the earlier period which represents totally nomadic bison hunters who left little trace of their occupation of the land (Brown et al. 1982). The later period represents the historic Comanche Indians who came to dominate the region in the eighteenth century. Apparently the acquisition of the horse was responsible for the final distribution of major aboriginal groups across the state and to a large extent determined cultural changes and settlement patterns that persisted in this Study Unit. 


\section{CONCLUSIONS}

Because of the lack of artifacts--especially diagnostic tools--from Site 41NL20, the site can not be placed within one of the defined study units for the area. Therefore, little can be said regarding the interpretation of the site or its significance within the established framework. Few conclusions can be drawn regarding period of occupation, activities performed at the site, duration of habitation, cultural group, subsistence, or any other significant factor.

Since Sweetwater Creek is one of only a few reliable streams in the area, it is logical that many aboriginal groups would have camped along its banks throughout prehistory. Probably that portion of aboriginal occupation contained within the County Road 216 right-of-way and easement is peripheral to a larger site or sites along the terrace or possibly it represents an ephemeral occupation of short duration.

Whatever the case, that portion of Site 41NL20 within the current SDHPT jurisdiction is not deemed eligible for inclusion within the National Register of Historic Places nor desirable for nomination as a State Archeological Landmark. No further work is recommended for that portion of the site within the present right-of-way limits of County Road 216 or its temporary easement. 


\section{REFERENOES CIIED}

Brown, Theodore M., Kay L. Killen, Helen Simons, and Virginia Wolfkuhle 1982 Resource Protection Planning Process for Texas. Texas

Historical Commission. Austin.

Lowther, A.C.

1981

Soil Survey of Nolan County, Texas. United States Department of Agriculture Soil Conservation Service in cooperation with Texas Agricultural Experiment Station. 